Relations industrielles

Industrial Relations

\title{
Are Conclusions of Union Commitment Robust to Empirical Techniques Employed?
}

\section{Chockalingam Viswesvaran et Satish P. Deshpande}

Volume 48, numéro 3, 1993

URI : https://id.erudit.org/iderudit/050877ar

DOI : https://doi.org/10.7202/050877ar

Aller au sommaire du numéro

Éditeur(s)

Département des relations industrielles de l'Université Laval

ISSN

0034-379X (imprimé)

1703-8138 (numérique)

Découvrir la revue

Citer cet article

Viswesvaran, C. \& Deshpande, S. P. (1993). Are Conclusions of Union Commitment Robust to Empirical Techniques Employed ? Relations industrielles / Industrial Relations, 48(3), 539-558.

https://doi.org/10.7202/050877ar
Résumé de l'article

The Relationship Between Union Commitment and Gender : Some Qualifying Factors
Tous droits réservés (C) Département des relations industrielles de l'Universite Laval, 1993
Ce document est protégé par la loi sur le droit d'auteur. L'utilisation des services d'Érudit (y compris la reproduction) est assujettie à sa politique d'utilisation que vous pouvez consulter en ligne.

https://apropos.erudit.org/fr/usagers/politique-dutilisation/ 


\title{
Are Conclusions of Union Commitment Robust to Empirical Techniques Employed?
}

\author{
Chockalingam Viswesvaran \\ and
}

Satish P. Deshpande

This paper examines the determinants of union commitment using correlation, regression, and path analysis techniques as commonly employed. Emphasis is given to the potential differences which may stem from the use of alternative statistical techniques. Given increased use in industrial relations of regression methods, and more recently of path analysis methods, it is important to understand the extent and nature of differences that may be methodology-related. For the particular model and data analyzed differences in inferences from the alternative methods are relatively minor when comparing the regression and path analysis results, but these two methods yield results substantially different from those generated by correlational methods.

The hypothesized relationships in any topic area are subject to empirical verification. The statistical methods usually employed for this verification are regression, correlation, or path analytic techniques. Though additional methods exist like Manova, logit analysis and so on, such special methods are applicable for investigating only certain research questions (and only when the data are available in certain form). Given the range of available methods, a natural question that arises is whether the choice of the research method affects the conclusions or the implications inferred. This is a more general problem that University.

* Viswesvaran, C., Assistant Professor of Psychology, Florida International DeshPande, S.P., Associate Professor of Management, Western Michigan University.

** The authors thank Dr. Jack Fiorito for providing the data and many useful comments on an earlier version of the manuscript. An carlier version of this paper was presented at the poster session of 1992 Industrial Relations Research Association meetings in New Orleans, LA. 
could be answered by choosing a research topic examinable by these methods, and applying them to the same dataset.

The importance of such a study comparing the conclusions drawn when different methods are employed lies in its implications for both theory and practice. Most of the research in the industrial relations literature employs multiple regression analysis, but when investigating relationships that involve direct and indirect influences among variables, the adequacy of multiple regression analysis to model such direct and indirect effects requires investigation. Though some researchers have examined issues involving indirect relationships (McShane 1986; Premack and Hunter 1988) by path analysis, a comparison of the inferences deduced from such analyses with those inferred from regression or correlation analyses of the same issue and data has not been attempted in the industrial relations literature.

A comparison of the conclusions drawn from correlation and regression analysis has been conducted for issues like bargaining outcomes (Anderson 1979a), local union participation (Anderson 1979b), local union democracy (Anderson 1978), and arbitrator acceptability (Briggs and Anderson 1980). But no research study in any substantive area of industrial relations has compared the results obtained between path analysis and either correlation or regression approaches. By comparing the results obtained from all the three approaches applied to a model of union commitment with the same data, this study addresses a neglected but important concern in the field.

Such a research study basically attempts to answer three concerns. The first involves the issue of whether there exist research questions with certain characteristics that are amenable only to a particular method (e.g., path analysis). The second concern addresses the additional test statistics (e.g., partial and semipartial correlations) required by different methods to model the indirect relationships. The answer to these two concerns could be culled from books on statistics and structural equation models. The third concern in such a research study addresses the extent to which implications could vary when different methods are applied to a model involving indirect relationships among the variables (i.e., the extent to which implications could vary when a multiple regression analysis is applied to a model involving indirect relationships among the variables, from the implications inferred by a path analysis of the same model). This question is important because most empirical studies in industrial relations don't report partial and semipartial correlations but merely investigate the significance of regression weights in a model where the independent variables may be causally related among themselves. This last question involving a data-specific and model-specific examination will be examined in this paper. While we may conclude that the selection of methods affects the conclusions drawn (if it does), we can not conclude the opposite if 
the conclusions are the same. All we can say with confidence is that for the data and model under consideration the choice of research method does not affect the conclusions drawn. Nonetheless, we could derive at least weak inferences regarding the sensitivity of conclusions to statistical method with in the domain of the topic studied, in this instance, union commitment.

In this study a comparison of the results obtained when the three commonly employed methods - correlation, regression and path analysis - are used to model the determinants of union commitment is provided. Commitment, being a fundamental prerequisite for the success of any organization, has been investigated widely (e.g., Fukami and Larson 1984; Gallagher and Clark 1989). A knowledge of the factors influencing commitment and the mechanism by which this influence is effected are of practical importance to the organization, while academically such knowledge provides the basis for theory building and verification in the broad domain of individualorganization relationships. Before practical suggestions are implemented one must be sure of the stability and robustness of the conclusions when different analytical methods are employed. The question of whether the analysis method affects the conclusions drawn is of critical concern here because direct and indirect relationships have been hypothesized.

First, the previous research on union commitment is reviewed. Then the underlying theory, along with the empirical results obtained are presented. A model of union commitment is developed and, the direct and indirect relationships among the variables are hypothesized. The proposed model of union commitment is then tested by all three methods and inferences are compared across methods.

\section{PREVIOUS RESEARCH ON UNION COMMITMENT}

\section{Theory}

Commitment of its members is a fundamental prerequisite for the success of any voluntary association. Commitment is the foundation on which any labor movement is based. The effectiveness of unions in organizing, bargaining, retaining membership, getting the participation of members in union activities, and success in political action taken by the union is dependent, to a great extent, on the level of commitment the union is able to generate among its members (Gordon et al. 1980). As such the determinants of commitment is an important area of research in industrial relations. The process by which commitment is built up, the factors influencing commitment and the resultant outcomes of commitment have been extensively studied. 
Initial research in the area of union commitment considered commitment as a zero-sum commodity, which postulates that commitment to a union precludes commitment to the employing institution. This mutual exclusivity principle stimulated interest in investigating the extent to which union growth competed with loyalty to the employing organization. However, several empirical studies (Dean 1954; Purcell 1953; Stagner 1954) indicated a positive relationship between company and union commitment, which contradicted the zero sum theory and led to the formulation of the concept of dual commitment or dual loyalty. This positive relationship between company and union commitment was found to be a function of the perceived labor-management relationships existing in the workplace between the unions and the employer (Angle and Perry 1986).

To measure union commitment, scales parallel to the "organizational commitment questionnaire" (OCQ) scale (Porter et al. 1976) have been constructed. Some scales are unidimensional (Porter et al. 1976), while others model union commitment as a multidimensional concept (Gordon et al. 1980). The Gordon scale identifies four dimensions of union commitment: union loyalty, responsibility to the union, willingness to work for the union, and belief in unionism.

Based on previous research and the theory developed in the organizational commitment literature, several antecedent variables of union commitment have been identified (Gallagher and Clark 1989), which could be classified into four categories: variables indicating the demographic characteristics of the workforce, experiences with the job and employer, labor-management climate, and union socialization experiences. The demographic variables includes characteristics such as age, gender, education level, and job tenure of the employees. The experiences with the job and employer could be summarized with variables like organizational commitment, job satisfaction (both intrinsic and extrinsic), and attitudes towards the supervisor. The labor relations climate is indicated by variables such as the perceptions of the employee about the quality of labor-management relations and the employee's attitudes towards the grievance procedure. The union experiences that affect an employee's union commitment include socialization processes, knowledge of the contract, perceptions of the union steward, and previous union affiliations.

A more useful classification of these variables from the union viewpoint is to classify them according to the degree of control that the union has over them (Gallagher and Clark 1989). Demographic variables are beyond the control of the unions except in closed hiring hall situations. The perceptions of the union steward are largely under union control, while variables like job satisfaction and quality of labor-management relationships could be influenced by both the union and the employer. 


\section{Empirical Results in Prior Research}

Empirical results indicate that women are more committed to unions than men when an overall measure of commitment is employed. The above result holds for attitudinal measures of commitment, suggesting that women have more positive affective orientations toward a union than do men, but when behaviorally oriented measures of commitment such as the willingness to work for the union or responsibility to the union were employed, men exhibited more commitment. This dichotomy between attitude and behavior could be attributed to the lack of opportunity and ability to participate for women due to gender-specific child care responsibilities or discrimination.

The empirical relationship between age and union commitment is mixed, with some studies reporting a positive relationship between age and unidimensional measures of commitment or the responsibility to the union dimension (Martin et al. 1987; Conlon and Gallagher 1987). Similarly, it is difficult to draw any definitive conclusions between union commitment and job tenure or education level of the members.

Previous empirical analyses indicate support for the concept of dual commitment. Job satisfaction was found to be positively related to company commitment and extrinsic job satisfaction indicated a definite positive relationship with union commitment (Gordon et al. 1984) but the relationship between intrinsic job satisfaction and union commitment was ambiguous. Empirical support exists for the view that an employee with a poor relationship with a supervisor may perceive the union as a protector and hence display higher union commitment levels (Martin et al. 1982).

A positive relationship has been found between the perceived quality of labor-management relations and union commitment levels, lending further support to the concept of dual commitment (Fukami and Larson 1984; Angle and Perry 1986). Further, it was found that when employees view participation programs as improving labor-management relations, their union commitment levels increase. Satisfaction with the existing grievance procedure was found to have a positive relationship with union commitment (Clark et al. 1988).

Irrespective of whether unidimensional (Fukami and Larson 1984) or multidimensional (Gordon et al. 1980) measures of commitment were employed, socialization experiences played a significant role in determining commitment levels. This relationship is consistent with the theory in organizational entry. Knowledge of the contract also had a positive impact on commitment levels (Clark et al. 1988; Martin et al. 1982).

\section{THE PROPOSED UNION COMMITMENT MODEL}

The causality of some of the relationships mentioned above could very easily be reversed. Though longitudinal data could be employed to investigate 
the causal nature, the question of whether behavior shapes attitudes or attitudes shape behavior is the proverbial chicken and egg problem. This problem is more acute when relationships between attitudinal variables are considered. In this paper, our aim is to specify a particular model of relationships among relevant variables, identify the test statistics required to test those relationships by correlation, regression, or path analytic approaches, and examine the comparability of the results obtained by those methods. A brief description of the variables used along with their means and standard deviations is provided in Table 1.

TABLE 1

Description of Variables Used

\begin{tabular}{|c|c|c|}
\hline Variable & Definition & $\begin{array}{l}\text { Mean } \\
(S D) \\
{[N]}\end{array}$ \\
\hline 1. UC & $\begin{array}{l}\text { A composite measure of union commitment capturing the willing- } \\
\text { ness to work for the union, belicf in unionism, etc. of the } \\
\text { respondents }\end{array}$ & $\begin{array}{c}70.942 \\
(12.810) \\
{[173]}\end{array}$ \\
\hline 2. JS & $\begin{array}{l}\text { A composite mcasure of job satisfaction that captures the respon- } \\
\text { dent's satisfaction with benefits and working conditions }\end{array}$ & $\begin{array}{l}48.115 \\
(9.438) \\
{[174]}\end{array}$ \\
\hline 3. EP & $\begin{array}{l}\text { A measure reflecting the attitude of the respondents towards their } \\
\text { immediate supervisor }\end{array}$ & $\begin{array}{l}19.680 \\
(5.075) \\
{[178]}\end{array}$ \\
\hline 4. LMR & $\begin{array}{l}\text { A measure of the respondent's pereeptions regarding the quality of } \\
\text { labor management relationships }\end{array}$ & $\begin{array}{l}28.661 \\
(6.466) \\
{[168\}}\end{array}$ \\
\hline 5. UAFF & $\begin{array}{l}\text { A two item index assessing the association of the respondent's par- } \\
\text { ents with unions }\end{array}$ & $\begin{array}{l}2.721 \\
(.712) \\
{[165]}\end{array}$ \\
\hline 6. FRIENDS2 & $\begin{array}{l}\text { A Likert type question on a 5-point scale assessing how many of } \\
\text { the respondent's friends are union members }\end{array}$ & $\begin{array}{l}2.457 \\
(.092) \\
{[178]}\end{array}$ \\
\hline 7. AGE & A 12-point scale assessing the age of the respondent & $\begin{array}{l}6.298 \\
(2.003) \\
{[181]}\end{array}$ \\
\hline 8. SEX & Sex of the respondent & $\begin{array}{l}.816 \\
(.389) \\
{[174]}\end{array}$ \\
\hline 9. GENATT & $\begin{array}{l}\text { A } 10 \text { item composite index measuring the general affect of the } \\
\text { respondent towards unions }\end{array}$ & $\begin{array}{l}38.815 \\
(6.814) \\
{[178]}\end{array}$ \\
\hline 10. USOC & $\begin{array}{l}\text { A measure assessing the socialization experiences of the respon- } \\
\text { dent with the union }\end{array}$ & $\begin{array}{l}3.503 \\
(1.874) \\
{[177]}\end{array}$ \\
\hline
\end{tabular}


The union commitment level of an employee is hypothesized to depend on job satisfaction levels (both extrinsic and intrinsic), perceptions of the quality of labor management relationships, union socialization experiences, and on general attitude towards unions. The relationship between demographic variables and union commitment levels could be explained by the differences in general attitudes towards unions among the different demographic groups which in turn stem from group-specific experiences. Prior union affiliation (self or that of significant others) will have an indirect effect on union commitment levels by affecting the general attitudes towards unions. Perceptions of the union steward's availability and efficiency were found to play a key role in the union commitment levels (Fields, Masters, and Thacker 1987; Clark et al. 1988). Also, positive perception of the stewards and other positive union socialization experiences affects the general attitude towards unions. Additionally, perceptions regarding the supervisor will affect job satisfaction levels. Perceptions of the labor-management relations will affect the views of the employees regarding the general attitudes towards the unions and supervisors. These relationships are depicted in Figure 1.

FIGURE 1

The Proposed Model

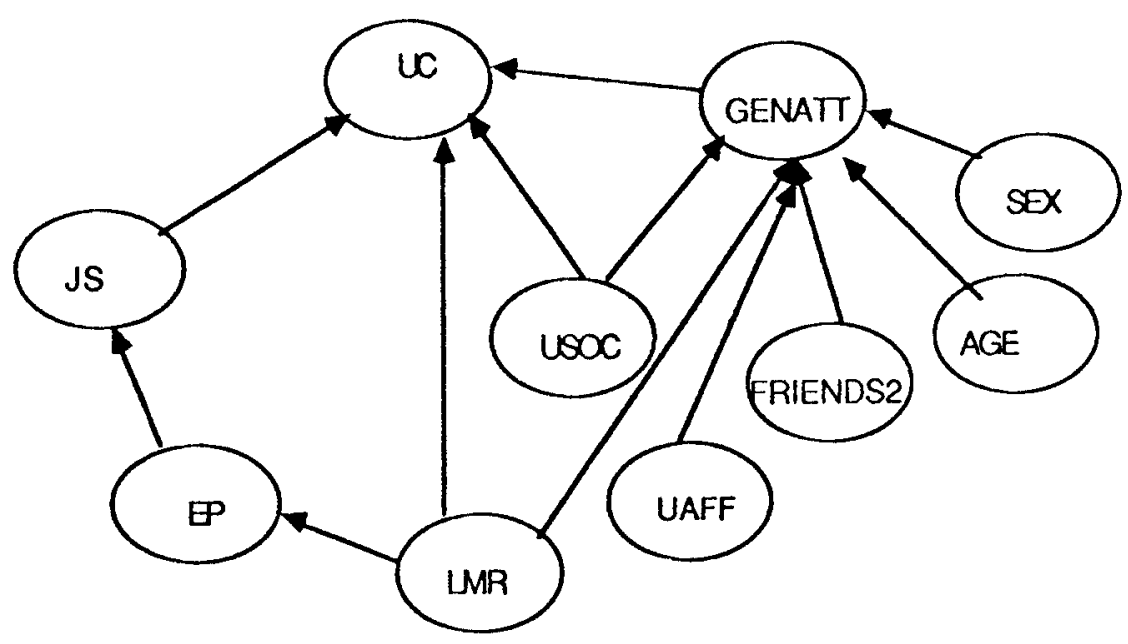


The main hypotheses that have to be tested in the proposed model of union commitment as shown in Figure 1, are:

(1) Job satisfaction, perceived quality of labor management relationships, union socialization experiences, and general attitudes towards unions have a direct effect on union commitment level;

(2) The effect of previous union affiliation and demographic characteristics on union commitment levels is only through their effects in influencing the general attitude towards unions; The union affiliation of the respondent's significant others will have an indirect effect on union commitment levels by affecting the general perception of unions;

(3) Perceptions about the quality of labor-management relations will affect the general attitudes towards the unions and supervisors, and will also have a direct influence on the union commitment levels;

(4) Union socialization experiences will have a direct effect on union commitment levels and an indirect effect through its influence on general attitudes towards unions;

(5) Attitudes towards the supervisor will affect the union commitment level as an indirect effect through its influence on job satisfaction.

In the next section, we briefly discuss the basis of three approaches correlation, regression, and path analysis - that could be employed to test these relationships. After identifying the test statistics to be computed in each approach, we describe the data set used in this study, along with the measures developed for the variables of interest.

\section{THE THREE APPROACHES}

\section{Correlational Approach}

The correlation coefficient is a number between -1 and +1 that indicates the direction and strength of the linear relationship between two variables. These bivariate correlations are a sufficient indicator of the linear relationship between variables. Since normally distributed variables can't have a curvilinear relationship, the correlation coefficient between two normally distributed variables is an indicator of the total relationship between them; when that coefficient is zero the researcher can conclude the variables are independent if bivariate normality holds (otherwise one can conclude that there is no linear relationship).

When the relationship between two variables is moderated by another variable or the predictability of one variable by another is increased by a third variable, additional test statistics have to be computed to test the proposed 
relationships among the variables. If the variables are correlated among themselves, a measure of the unique influence between two variables is the partial correlation coefficient. If on the other hand, the researcher is interested in knowing the unique contribution made by an independent variable to the predictability of the dependent variable, the semipartial correlation is an appropriate statistic (i.e., partial out the effects from the other independent variables).

For the proposed model of union commitment the main correlations of interest for testing the first hypothesis are the correlations of union commitment levels with job satisfaction, perceived quality of labor management relationships, union socialization experiences, and general attitudes towards the unions. The second hypothesis implies that the semipartial correlations of union commitment levels with union affiliation or demographic characteristics with general attitudes partialled out has to be zero. For the third hypothesis to hold, the semipartial correlations between the perceptions of labormanagement relations and union commitment levels with the attitudes towards the supervisors and unions partialled out has to be nonzero. The test statistic to verify the fourth hypothesis is the semipartial correlation between union socialization experiences and union commitment with general attitudes towards the unions being partialled out. This semipartial should not be zero to support the hypothesis. To investigate the final hypothesis, the test statistic required is the semipartial correlation between attitudes towards the supervisor and union commitment levels with job satisfaction partialled out from supervisor attitudes. If that statistic is zero, then we can infer support for our fifth hypothesis that attitudes toward supervisors exerts only an indirect effect on union commitment levels.

Thus, though the five advanced hypotheses could be tested correctly by correlational methods, the common approach involves the interpretation based on simple correlation coefficients. These inferences are compared in the results section with the inferences drawn from the regression and path analytic models.

\section{Regression Approach}

The regressional approach involves the development of a functional relationship between the dependent variable with the independent variables. It is an attempt to predict the dependent variable given the information on the independent variables. Though several criteria could be developed to find this prediction function, the most commonly used criterion is least squares which attempts to minimize the sum of the squared errors between the predicted and observed values of the dependent variables. It will be difficult to model the relationship between two variables which is exclusively through their 
relationship to a third variable (indirect effects). The common approach in such instances is to test for an interaction term.

Thus multiple regression analysis does not account for the indirect relationships, but could identify the additional variance explained in union commitment by an interaction term given that all other variables are already in the model. Typically a researcher employing multiple regression analysis will include the above variables as independent variables in a model with union commitment as the dependent variable. The emphasis would be to test the significance of the regression weights. This approach tells us whether the variable under question makes a significant improvement in the prediction given the other variables. This improvement could be the result of either the direct relationship or due to some indirect relationship with other independent variables. Multiple regression analysis as commonly applied has no way of resolving this ambiguity.

However, as noted earlier the usual procedure is to develop one OLS regression model with union commitment as the dependent variable and the other variables such as job satisfaction, demographics, attitudes towards supervisors, and perceived quality of labor-management relationships as the independent variables. The regression weights obtained are analyzed for sign and significance to infer the conclusions. Such conclusions are compared with those drawn from correlational and path analytic models in the results section.

\section{Path Analysis}

Structural equation models or path analytic models are employed to test the implications of causal relationships for observable correlations. The problem of rendering a causal interpretation of observed correlations rests with theory specification. These causal models, by explicitly stating the indirect relationship, make sure that such indirect associations between variables are tested.

Lisrel VII (Joreskog and Sorbom 1988) was used to analyze the proposed path model. In addition to providing the significance of each path this program also provides overall goodness of fit indices such as chi square statistics, goodness of fit indices, and root mean square residual. Excessive reliance on the chi square statistic is not advisable since that statistic depends on sample size (Bentler and Bonett 1980). The input to the program was the zero order intercorrelations among the variables.

\section{DATA SET EMPLOYED}

The data set comprises the responses of 181 union members on various constructs such as job satisfaction, union commitment, etc. The 181 respon- 
dents (of the 600 surveyed) were members of three different unions: Teamsters $(n=54)$, a state government employees union $(n=74)$, and a postal union $(n=53)$ in a midwestern state. $81.6 \%$ of the respondents were males. An average respondent had worked for his/her employer for 206 months and was a union member for 197 months. $50.3 \%$ of the respondents had been union members at their previous employment.

Union commitment (UC) is measured as the total score on the responses to nineteen questions reflecting the respondents' sense of belonging, willingness to work for the union, and so on. Some of the negatively worded questions were reverse coded, so that a high total score indicates a high union commitment. Similarly scores were obtained for job satisfaction (JS), general attitudes towards unions (GENATT), and perceptions of labor management relationship variables (LMR). Questions on job satisfaction captured the respondents' satisfaction with pay, fringe benefits, job security, working conditions, availability of intrinsic rewards, support relationships, freedom/autonomy on the job, and an overall assessment of the job. While questions about general union attitudes focused on the respondents' perceptions of unions in society, job satisfaction measures stressed the conditions in the specific individual's workplace.

Union affiliation scores were obtained by adding the scores in the responses to two items which separately solicited whether the respondent's father had been a union member, and whether the respondent's mother had been a union member. Another variable, FRIENDS2, reflects how many of the respondent's friends are union members (on a likert-style scale ranging from "none" to "almost all"). These three variables together provide an indication of the association of the respondent's "significant others" with unions. The sex of the respondent was coded as $0 / 1$ for female/male.

\section{RESULTS}

The correlations among the ten variables are presented in Table 2 while the results of the regressional analyses are provided in Table 3. Note that the attitudes towards supervisors which has a small positive nonzero correlation "change sign" in the regression analysis. More important is the fact that perceptions of labor management relationships, which has a significant $(p<0.05)$ positive correlation, change its sign (but is not significant) in the regression results. Though the other variables have the same sign, only two variables (GENATT and FRIENDS2) are significantly $(\mathrm{p}<0.001)$ different from zero when the combined effects are considered in regression analysis, while three variables (GENATT, JS, FRIENDS2) have significant $(p<0.001)$ nonzero positive zero order correlations. For a significance value of $p<0.005$ correlational analysis yield five significant relationships while regression yield only 
two relationships. At a significance level of $p<0.05$ correlational analysis provides six significant relationships while regression results show only three variables to be significant.

TABLE 2

Results of Correlation Analysis (p values) [N]

\begin{tabular}{|c|c|c|c|c|c|c|c|c|c|c|}
\hline Variables & 1 & 2 & 3 & 4 & 5 & 6 & 7 & 8 & 9 & 10 \\
\hline 1. UC & $\begin{array}{c}.938 \\
{[173]}\end{array}$ & & & & & & & & & \\
\hline 2. GENATT & $\begin{array}{c}.713 \\
(.000) \\
{[171]}\end{array}$ & $\begin{array}{c}.873 \\
{[178]}\end{array}$ & & & & & & & & \\
\hline 3. JS & $\begin{array}{c}.255 \\
(.001) \\
{[169]}\end{array}$ & $\begin{array}{c}.219 \\
(.004) \\
{[171]}\end{array}$ & $\begin{array}{c}.877 \\
{[174]}\end{array}$ & & & & & & & \\
\hline 4. EP & $\begin{array}{c}.017 \\
(.821) \\
{[172]}\end{array}$ & $\begin{array}{c}.070 \\
(.355) \\
{[176]}\end{array}$ & $\begin{array}{c}.490 \\
(.000) \\
{[172]}\end{array}$ & $\begin{array}{c}.897 \\
{[178]}\end{array}$ & & & & & & \\
\hline 5. LMR & $\begin{array}{c}.165 \\
(.036) \\
{[162]}\end{array}$ & $\begin{array}{c}.242 \\
(.002) \\
{[167]}\end{array}$ & $\begin{array}{c}.389 \\
(.000) \\
{[164]}\end{array}$ & $\begin{array}{c}.446 \\
(.000) \\
{[167]}\end{array}$ & $\begin{array}{c}.937 \\
{[168]}\end{array}$ & & & & & \\
\hline 6. USOC & $\begin{array}{c}.242 \\
(.001) \\
{[172]}\end{array}$ & $\begin{array}{c}.265 \\
(.000) \\
{[174]}\end{array}$ & $\begin{array}{c}.130 \\
(.087) \\
{[174]}\end{array}$ & $\begin{array}{c}.074 \\
(.328) \\
{[175]}\end{array}$ & $\begin{array}{c}.116 \\
(.136) \\
{[166]}\end{array}$ & $\begin{array}{c}.697 \\
{[177]}\end{array}$ & & & & \\
\hline 7. UAFF & $\begin{array}{c}.227 \\
(.004) \\
{[158]}\end{array}$ & $\begin{array}{c}.109 \\
(.165) \\
{[163]}\end{array}$ & $\begin{array}{l}-.028 \\
(.726) \\
{[162]}\end{array}$ & $\begin{array}{c}.006 \\
(.941) \\
{[162]}\end{array}$ & $\begin{array}{c}.093 \\
(.254) \\
{[153]}\end{array}$ & $\begin{array}{c}.114 \\
(.147) \\
{[162]}\end{array}$ & $\begin{array}{c}.479^{\star} \\
{[162]}\end{array}$ & & & \\
\hline 8. FRIENDS2 & $\begin{array}{c}.307 \\
(.000) \\
{[171]}\end{array}$ & $\begin{array}{c}.112 \\
(.138) \\
{[175]}\end{array}$ & $\begin{array}{c}.063 \\
(.414) \\
{[172]}\end{array}$ & $\begin{array}{c}.066 \\
(.383) \\
{[175]}\end{array}$ & $\begin{array}{c}.096 \\
(.219) \\
{[165]}\end{array}$ & $\begin{array}{c}.061 \\
(.422) \\
{[175]}\end{array}$ & $\begin{array}{c}.272 \\
(.000) \\
{[165]}\end{array}$ & $\begin{array}{l}1.000 \\
{[178]}\end{array}$ & & \\
\hline 9. AGE & $\begin{array}{c}.099 \\
(.195) \\
{[173]}\end{array}$ & $\begin{array}{c}.053 \\
(.486) \\
{[178]}\end{array}$ & $\begin{array}{c}.220 \\
(.004) \\
{[174]}\end{array}$ & $\begin{array}{c}.004 \\
(.963) \\
{[178]}\end{array}$ & $\begin{array}{c}.129 \\
(.097) \\
{[168]}\end{array}$ & $\begin{array}{c}.150 \\
(.047) \\
{[177]}\end{array}$ & $\begin{array}{c}-.219 \\
(.005) \\
{[165]}\end{array}$ & $\begin{array}{c}.038 \\
(.616) \\
{[178]}\end{array}$ & $\begin{array}{l}1.000 \\
{[181]}\end{array}$ & \\
\hline 10. SEX & $\begin{array}{c}.094 \\
(.223) \\
{[169]}\end{array}$ & $\begin{array}{c}.069 \\
(.368) \\
{[172]}\end{array}$ & $\begin{array}{c}.064 \\
(.406) \\
{[168]}\end{array}$ & $\begin{array}{c}.044 \\
(.570) \\
{[172]}\end{array}$ & $\begin{array}{c}.086 \\
(.276) \\
{[162]}\end{array}$ & $\begin{array}{c}.007 \\
(.928) \\
{[171]}\end{array}$ & $\begin{array}{c}-.160 \\
(.043) \\
{[160]}\end{array}$ & $\begin{array}{c}.094 \\
(.220) \\
{[172]}\end{array}$ & $\begin{array}{c}.149 \\
(.049) \\
{[174]}\end{array}$ & $\begin{array}{l}1.000 \\
{[174]}\end{array}$ \\
\hline
\end{tabular}

* Since the reliability was low, the analysis was repeated with the two items as separate constructs; the conclusions did not differ. Diagonals show reliabilities (Cronbach's alpha) for multi-item scales. A value of 1.0 indicates a single item measure. 
TABLE 3

Combined and Independent Effects Analysis by Regression

\begin{tabular}{lccc}
\hline $\begin{array}{l}\text { Independent } \\
\text { variable }\end{array}$ & $\begin{array}{c}\text { Raw regression } \\
\text { weights }\end{array}$ & $\begin{array}{c}\text { Standardized } \\
\text { regression weights }\end{array}$ & t-ratio \\
\hline 1. GENATT & 1.271 & 0.646 & $10.460^{\star * *}$ \\
2. JS & 0.197 & 0.140 & $2.032^{*}$ \\
3. EP & -0.229 & -0.086 & -1.222 \\
4. LMR & -0.104 & -0.052 & -0.769 \\
5. USOC & 0.060 & 0.008 & 0.140 \\
6. UAFF & 0.892 & 0.113 & 1.815 \\
7. AGE & 0.213 & 0.033 & 0.511 \\
8. SEX & 0.471 & 0.013 & 0.211 \\
9. FRIENDS2 & 2.690 & 0.203 & $3.368 * \star \star$ \\
N & 140 & & \\
R $^{2}$ & 0.5839 & & \\
Adjusted ${ }^{2}$ & 0.5553 & & \\
\hline
\end{tabular}

* significant at $\mathrm{p}<0.05 ;{ }^{*}$ significant at $\mathrm{p}<0.01 ;{ }^{*}$ significant at $\mathrm{p}<0.005$;

$* \star *$ significant at $\mathrm{p}<0.001$

The results presented in Table 3 indicate both the combined effect of all nine independent variables, as well as the independent contribution of each variable. Another strategy is to consider in the regressional analysis only those independent variables that correlated significantly with the dependent variable and, did not pose "problems" of multicollinearity (Anderson 1978, 1979a; Briggs and Anderson 1980). Anderson (1978, 1979a) and Briggs and Anderson (1980) "define" problems of multicollinearity as a correlation at or above 0.60 among the independent variables in the intercorrelation matrix. Application of this strategy results in the inclusion of six variables in a regression equation the results of which are summarized in Table 4.

In regressional analysis, general attitudes and union affiliation of significant others seem to be the only determinant of significance $(p<0.01)$ in explaining the variance in union commitment levels. The proportion of variance explained in the union commitment levels by other variables is not significant. This conclusion holds whether the independent or combined effects are analyzed. In contrast the correlational model yielded three significant $(\mathrm{p}<0.01)$ correlations.

The standardized path coefficients are shown in Figure 2 with the $t$ values indicated within parentheses. The path from general attitudes to commitment levels is significant at $p<0.001$, one tailed test. The paths from job satisfaction 
TABLE 4

Regression Results Including only the Variables with Significant Zero-Order-Correlations

\begin{tabular}{lccc}
\hline $\begin{array}{l}\text { Independent } \\
\text { variable }\end{array}$ & $\begin{array}{c}\text { Raw regression } \\
\text { weights }\end{array}$ & $\begin{array}{c}\text { Standardized } \\
\text { regression weights }\end{array}$ & t-ratio \\
\hline 1. JS & 0.157 & 0.112 & 1.803 \\
2. LMR & -0.163 & -0.081 & -1.323 \\
3. USOC & -0.030 & -0.004 & -0.075 \\
4. GENATT & 1.299 & 0.660 & $10.976^{* * *}$ \\
5. UAFF & 0.812 & 0.103 & 1.746 \\
6. FRIENDS2 & 2.625 & 0.200 & $3.415^{* * *}$ \\
N & 140 & & \\
$\mathrm{R}^{2}$ & 0.5711 & & \\
Adjusted $\mathrm{R}^{2}$ & 0.5525 & & \\
\hline
\end{tabular}

${ }^{+}$significant at $\mathrm{p}<0.05 ;{ }^{*}$ significant at $\mathrm{p}<0.01 ;{ }^{* *}$ significant at $\mathrm{p}<0.005$;

$* * *$ significant at $\mathrm{p}<0.001$.

FIGURE 2

Path Analysis Results

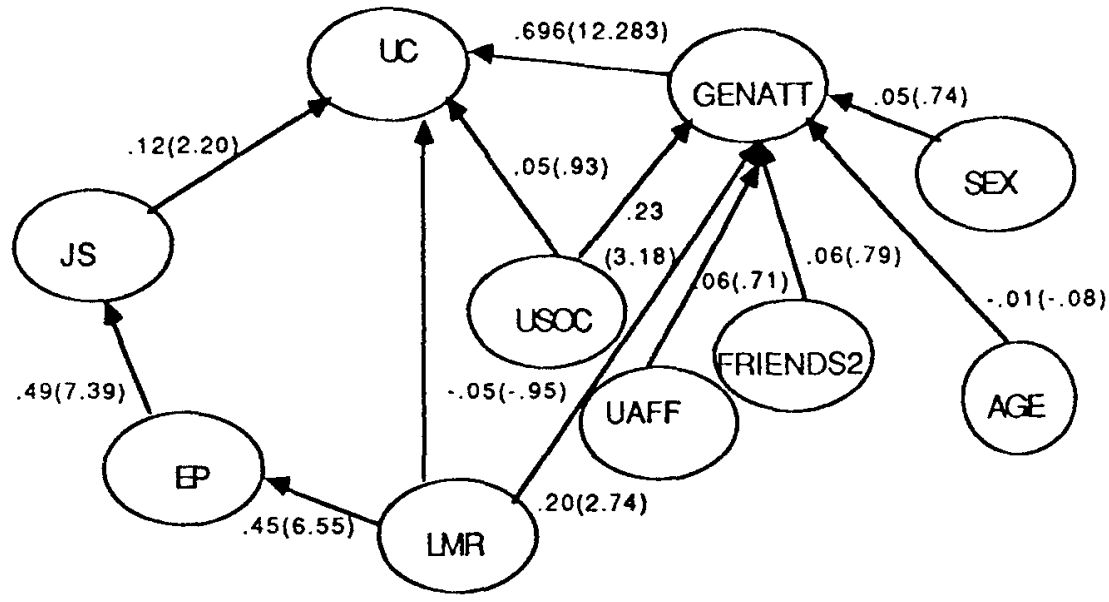

Figures in parentheses are t-values for the path coefficients. 
to commitment levels are significant at .05 while the path from union socialization experiences to general attitudes towards unions is significant at .005 levels. No other path is significant to the union commitment levels. The path between perceived quality of labor-management relationships and commitment levels is non-significant and has the same sign (negative) in both regression and path analysis. This means that the significant $(\mathrm{p}<0.05)$ positive zero order correlation between LMR and UC becomes non-significant (and negatively signed) when regression or path analytic results are considered.

The overall fit of the hypothesized model to the empirical data analyzed is indicated by Lisrel with indices such as the chi square statistic, goodness of fit index, adjusted goodness of fit index, and the root mean square residual. For this model the values turned out to be $55.710(\mathrm{DOF}=18, \mathrm{~N}=180), 0.944,0.830$, and 0.063 , indicating reasonable fit of the model to the data.

An examination of the modification indices show that allowing a direct path from perceptions of labor-management relationships to job satisfaction levels will reduce the chi square statistic by 8.488 , while freeing the AGE-JS path reduces the chi square by 11.228 . This implies that age of the respondent and the perceptions of the quality of labor management relations have direct effects on the job satisfaction levels. Though such direct effects could be justified on theoretical grounds, we don't include them here, since modifying the model based on modification indices (data snooping) is not advisable. Future studies might consider these relationships for empirical testing.

The effects of the nine independent variables on the union commitment levels as assessed by each of the three models (correlation, regression and path analysis) are summarized in Table 5.

TABLE 5

Comparison of Results Across Methods

\begin{tabular}{|c|c|c|c|}
\hline $\begin{array}{l}\text { Independent } \\
\text { variable }\end{array}$ & Correlation & Regression ${ }^{b}$ & Path analysis \\
\hline 1. GENATT & $0.713^{* * *}$ & $0.646^{\star \star \star}$ & $0.696 * * *$ \\
\hline 2. JS & $0.255^{\star \star \star}$ & $0.140^{+}$ & $0.120^{+}$ \\
\hline 3. EP & 0.174 & -0.086 & $-{ }^{\circ}$ \\
\hline 4. $\mathrm{LMR}$ & $0.165^{+}$ & -0.052 & -0.054 \\
\hline 5. USOC & $0.242^{* *}$ & 0.008 & 0.051 \\
\hline 6. UAFF & $0.227^{\star *}$ & $0.113^{d}$ & $-c$ \\
\hline 7. FRIENDS2 & $0.307 * \star \star$ & $0.203^{* * *}$ & $-{ }^{c}$ \\
\hline 8. AGE & 0.099 & 0.033 & $-c$ \\
\hline 9. SEX & 0.094 & 0.013 & $-c$ \\
\hline
\end{tabular}

'Zero order correlations; ${ }^{b}$ Standardized regression weights; ${ }^{\text {' Omitted path coefficients; }{ }^{\mathrm{d}} \mathrm{Had} \text { a }}$ p-value of .07

significant at $p<0.05 ;{ }^{*}$ significant at $p<0.01 ; * *$ significant at $p<0.005$;

$* * *$ significant at $\mathrm{p}<0.001$ (all one tailed tests) 
Job satisfaction which has a highly significant $(p<0.001)$ zero order correlation with union commitment is significant at $p<0.05$ in path analysis and is significant at $p<0.044$ in regression analysis. In general, the results from the three methods are quite similar in qualitative terms. A notable difference, however, arises for the union socialization variable which evidences a strong positive relation with union commitment in the correlation results but virtually no relation in either the regression or path analysis models.

\section{DISCUSSION}

There are three questions of concern here: Can the research questions of interest, regardless of their indirect relationships, be modelled by any technique? Second, if they are tested by different techniques with the appropriate statistic, will the conclusions be different? Finally, in examining commonly used statistics generated by alternative techniques (simple correlations in correlation model, regression weights in regression analysis) will the conclusions differ?

If the first question is answered in the affirmative but the other two are in the negative, then there is no concern about the technique or the statistic to be employed in the study. Results of this study indicate that there are no major differences in conclusions implied by regression and path analysis for the model and data analyzed but some erroneous conclusions could be drawn from the correlation analysis. Thus, the choice of the method affects the inferences drawn only if the relationships are weak. Very strong relationships are not affected.

These results could be generalized by identifying a data base and a research question amenable to many techniques should be tested with alternate methods. In effect, answering the question "Is there an appropriate technique for a particular research question" requires further investigation. This study is preliminary in nature and the impact of the research question's characteristics requires further investigation.

The overall substantive conclusion inferable from these analyses is that the general attitude towards the unions is the major determinant of union commitment levels. This is consistent with the existing research, and underscores the importance of attempts by unions to gain acceptance by the society. The significant association found between union commitment levels and the affiliation of the respondent's significant others with unions in both correlation and regression analysis, along with the large modification indices for the path between significant others' affiliation and union commitment levels, implies that the affiliation of the respondent's significant others with unions has a direct impact on union commitment levels. This result underscores the impor- 
tance of subjective norms in similar contexts (e.g., Montgomery 1989). Also supported is the conclusion that job satisfaction plays a role in determining the union commitment levels of the respondents, while the importance of union socialization experiences seems questionable. Union socialization experiences which seemed to have a significant bearing on commitment levels when bivariate relations were considered were not found to be of any direct significance in either path or regression analysis.

This result may of course reflect unique characteristics of the sample, but it is one worthy of further investigation. Much of the prior literature reports a positive socialization-commitment relation, and consequently policy prescriptions stress member orientation programs and the like as means of building union commitment. Our results suggest that if socialization programs enhance commitment, it is through their effect on general attitudes towards unions. Whether this implies that socialization programs, public relations campaigns, or other activities are the most effective means for building union commitment cannot be determined at present. The results clearly suggest, however, need for a better understanding of the process by which general attitudes toward unions are formed.

\section{REFERENCES}

Anderson, J.C. 1978. "A Comparative Analysis of Local Union Democracy." Industrial Relations, Vol. 17, 278-296.

ANDERSON, J.C. 1979a. "Bargaining Outcomes : An IR System Approach." Industrial Relations, Vol. 18, 127-143.

ANDERSON, J.C. 1979b. "Local Union Participation : A Re-Examination." Industrial Relations, Vol. 18, 18-31.

ANGle, H.L., and J.L. Perry. 1986. "Dual Commitment and Labor-Management Relationship Climates." Academy of Management Journal, Vol. 29, 31-50.

BENTLER, P.M., and D.G. BonetT. 1980. "Significance Tests and Goodness of Fit in Analysis of Covariance Structures." Psychological Bulletin, Vol. 88, 588-606.

BRIGGS, S.S., and J.C. ANDERSON. 1980. "An Empirical Investigation of Arbitrator Acceptability." Industrial Relations, Vol. 19, 163-174.

Clark, P.F., D.G. Gallagher, and T. Pavlok. 1988. The Role of the Grievance Procedure in Shaping Member Commitment to the Union. Working Paper, Department of Labor Studies and Industrial Relations, Pennsylvania State University.

CONLON, E.J., and D.G. GallaGHER. 1987. "Commitment to Employer and Union : Effects of Membership Status." Academy of Management Journal, Vol. 30, 151-162.

DEAN, L.R. 1954. "Union Activity and Dual Loyalty." Industrial and Labor Relations Review, Vol. 7, 526-536. 
Fieldd, M.W., M.F. Masters, and J.W. ThaCker. 1987. "Union Commitment and Membership Support for Political Action : An Exploratory Analysis." Journal of Labor Research, Vol. 8, 143-158.

Fukami, C.V., and E. LARSON. 1984. "Commitment to Company and Union: Parallel Models." Journal of Applied Psychology, Vol. 69, 640-644.

Gallagher, D.G., and P.F. Clark. 1989. "Research on Union Commitment: Implications for Labor." Labor Studies Journal, Vol. 14, 52-71.

Gordon, M.E., J.W. Philpot, R.E. Burt, C.A. Thompson, and W.E. SPILler. 1980. "Commitment to the Union: Development of a Measure and an Examination of its Correlates." Journal of Applied Psychology, Vol. 65, 479-499.

Gordon, M.E., L.L. Beauvais, and R.T. LADD. 1984. "The Job Satisfaction and Union Commitment of Unionized Employees.' Industrial and Labor Relations Review, Vol. 37, 359-370.

JoRESKOG, K.G., and D. SORBOM. 1988. Lisrel VII. Estimation of Linear Structural Equation Systems : Program Version 7.16. Scientific Software, Mooresville, Indiana.

Martin, J.E., J.M. Magenau, and M.M. Peterson. 1982. "Variables Differentiating Patterns of Commitment Among Union Stewards." Paper presented at the 42nd Annual Meeting of the Academy of Management, New York.

Martin, J.E., J.M. MAgenaU, and M.M. Peterson. 1987. "Two Tier Wage Structures : Implications for Equity Theory." Academy of Management Journal, Vol. 30, 297-315. MCShane, S.L. 1986. "A Path Analysis of Participation in Union Administration." Industrial Relations, Vol. 25, 72-80.

MONTGOMERY, B.R. 1989. "The Influence of Attitudes and Normative Pressures on Voting Decisions in a Union Certification Election." Industrial and Labor Relations Review, Vol. 42, 262-279.

PORTER, L.W., W.J. CROMPTon, and F.J. SMITH. 1976. "'Organizational Commitment and Managerial Turnover: A Longitudinal Study." Organizational Behavior and Human Performance, Vol. 15, 87-98.

PREMACK, S.L., and J.E. HuNTER, 1988. "Individual Unionization Decisions." Psychological Bulletin, Vol. 103, 223-234.

PuRCELl, T.V. 1953. The Worker Speaks his Mind on Company and Union. Cambridge : Harvard University Press.

Stagner, R. 1954. "Dual Allegiance as a Problem in Modern Society." Personnel Psychology, Vol. 7, 41-46.

\section{Les techniques d'analyses statistiques et l'engagement syndical}

Cet article traite des différents déterminants de l'engagement syndical utilisés par les principales techniques d'analyses statistiques, soit la corrélation, la régression et l'analyse par cheminement critique. Une attention particulière est accordée aux différences potentielles qui peuvent provenir du choix de la technique statistique. 
L'importance d'une comparaison entre les différentes conclusions découlant de l'utilisation de l'une ou des autres méthodes repose sur ses conséquences à la fois sur la théorie et sur la pratique. La plupart des recherches dont fait état la documentation en relations industrielles retiennent l'analyse de régression multiple. Mais lorsque les études examinent l'existence d'influences directes ou indirectes entre les variables, il n'est pas évident que l'analyse de régression multiple constitue la technique la plus appropriée. Bien que certains chercheurs se soient penchés sur des questions impliquant des liens indirects entre variables en utilisant des analyses par cheminement critique, une comparaison des conclusions tirées de telles analyses avec celles tirées à partir d'analyses de régression ou de corrélations n'a pas été tentée dans les études publiées en relations industrielles. En comparant les résultats obtenus de l'étude d'un modèle d'engagement syndical, sur la base des trois techniques d'analyse, cette recherche soulève une question importante, quoique négligée dans la littérature.

Trois objets retiennent en priorité l'attention. Le premier renvoie à la question visant à savoir s'il existe des questions de recherche comportant certaines caractéristiques qui ne peuvent faire l'objet que d'un type particulier d'analyse (par exemple, l'analyse par cheminement critique). Le second traite d'autres tests statistiques (par exemple, les analyses de corrélations partielles et semi-partielles) requis pour la modélisation des relations indirectes. Le troisième objet renvoie à la mesure dans laquelle les résultats et leurs conséquences peuvent varier selon le choix de la méthode à appliquer lorsque des relations indirectes entre variables sont en jeu (c'est à dire le différentiel entre les résultats découlant de l'analyse de régression multiple et ceux découlant de l'analyse par cheminement critique). Il importe de soulever cette question parce que la majorité des études empiriques en relations industrielles ne font pas état des corrélations partielles ou semi-partielles et se limitent à l'étude du niveau de signification des résultats de la régression à l'intérieur d'un modèle où les variables indépendantes peuvent conserver entre elles des liens de causalité.

Cette étude vise à comparer les résultats obtenus suite à l'utilisation des trois différentes méthodes les plus utilisées dont il est ici question. D'abord nous passons en revue la documentation sur l'engagement syndical. Puis, la théorie sous-jacente et les résultats empiriques obtenus sont présentés. Nous développons ensuite un modèle d'engagement syndical et nous en exposons les hypothèses eu égard aux relations directes et indirectes entre les différentes variables. Finalement, le modèle proposé d'engagement syndical est vérifié selon les trois méthodes statistiques et nous en présentons les résultats.

Les effets des neuf variables sur l'engagement envers l'institution syndicale sont évalués à la lumière de chacun des trois modèles (corrélation, régression et analyse par cheminement critique). Les résultats de cette étude indiquent qu'il n'existe pas de différences majeures entre les conclusions à tirer de l'analyse de régression par rapport à l'analyse par cheminement critique en regard des données et du modèle à l'étude, mais que des conclusions erronées peuvent être tirées de l'application de l'analyse de corrélation. Ainsi, le choix de la méthode affecte les conclusions dans la mesure où les liens existants sont faibles. Les relations très solides ne sont pas affectées.

La principale conclusion qui émerge de ces analyses est que l'attitude générale adoptée à l'endroit des syndicats constitue le déterminant majeur des niveaux 
d'engagement syndical. Cela ne s'impose pas à contre-courant des recherches existantes et souligne l'importance pour les syndicats de chercher à obtenir l'assentiment de la société. Les liens significatifs découverts entre les niveaux d'engagement face à l'institution syndicale et le fait que les proches des répondants soient affiliés à un syndicat montrent qu'un impact direct est causé par celui-ci sur ceux-là, tant pour l'analyse de régression que pour la corrélation. Ces résultats soulignent l'importance des normes subjectives dans des contextes similaires. Ils supportent également l'assertion selon laquelle la satisfaction au travail joue un rôle dans la détermination de ces niveaux d'engagement alors que l'importance des expériences de socialisation syndicale est contestable si l'on considère les effets directs de ces dernières en utilisant l'analyse de régression ou l'analyse par chemin critique.

\section{LES DÉFIS DE LA RÉMUNÉRATION}

Actes du XLVII ${ }^{*}$ Congrès des relations industrielles de l'Université Laval

Préface, Gilles LAFLAMME - Introduction. Gilles FERLAND - La rémunération: un art ou une science ?. THIERRY WILS et Christiane LABELLE - Les facteurs děvolution de la rémunération, William BROWN Commentaires: Gilles PAQUET - Les tendances en matière de rémunération, George T. MILKOVICH - Les pratiques de rémunération flexible : quelques expériences, Jean FULLER et Jean THIVIERGE - Commentaires: Jean-Guy FRENETTE - Quatre défis particuliers pour la rémunération : Le libre choix, Claude MARIER - Les entreprises en démarrage. Normand RHEAULT Léquité au travail. Esther DÉOM - Les stratégies syndicales, Claude RIOUX - Pratiques de rémunēration et capacité concurrentielle, Diane BELLEMARRE et Lise POULIN SIMON - Le rôle et lïmportance de la rémunération dans la gestion des ressources bumaines et la gestion des relations du travail, Roland THERIAULT et Joanne BERGERON - Commentaires : Clement GODBOUT.

ISBN $2 \cdot 7637-7313-3$

1 volume, 1992,163 pages, $23 \$$

LES PRESSES DE L'UNIVERSITÉ LAVAL

AVE. DE LA MÉDECINE, CITÉ UNIVERSITAIRE, STE-FOY, GIK 7P4 Tél. : (418) 656-5106 télécopieur : (418) 656-2600 